\title{
ФЕНОМЕН НЕЙТРАЛЬНОГО ДІАЛОГУ ЯК НЕОБХІДНИЙ ФАКТОР РЕАЛІЗАЦІЇ СУСПІЛЬНОї УГОДИ
}

\begin{abstract}
Ю.В. Панасюк
Існування людей неможливо уявити без активного спілкування, адже саме комунікація виступає основою соціального буття різноманітних людських спільнот. Проблеми комунікації привернули увагу дослідників особливо в XX ст., коли суспільний прогрес забезпечив інформативний простір новими механізмами міжособистісного спілкування. На нашу думку, діалог виступає в ролі самодостатньої структуроутворюючої одиниці такого спілкування. «Сучасна філософія діалогу розвивається в двох напрямках, в залежності від того, на який аспект діалогу - інформативний або особистісний - робиться акцент. Так, зображуючи в основному інформативний характер, діалог виступає як теорія мовних комунікацій, логіка дискурсу, інконтрологія і т. д. (основоположником такого підходу був Сократ).

Якщо ж розвивається особистісний аспект діалогу, то об'єктом аналізу є зустріч партнерів по діалогу, а діалог і подія зустрічі стають основою для філософствування. Засновником такого способу мислення став ще в XIX ст. Л. Фейєрбах, але частіше творцями філософії зустрічі вважають тих, хто знаходиться ближче всього до біблейсько-релігійної традиції Ф. Розенцвейга, М. Бубера, Є. Левінаса» [9, с. 1]. Серед філософів, які досліджували проблеми діалогу слід відмітити М. Бубера [2], О. Розеншток-Хюссі [7], Ю. Хабермаса [11], М. Фуко [10]. Вагомим також є внесок українських та російських дослідників В. Даренського [4], В. Демьянкова [5] та багатьох інших. Чи можна розглядати діалог лише з точки зору інформативного або особистісного аспектів? Чи $\epsilon$
\end{abstract}

Актуальні проблеми духовності:

зб. наук. праць / Ред.: Я.В. Шрамко

Вип. 10. - Кривий Ріг, 2009, 313-323 
діалог визначальним фактором реалізації суспільних відносин? Яким чином пов'язані поняття «діалог» та «дискурс»? Що представляє собою нейтральний діалог? На ці та інші запитання ми намагатимемося знайти відповіді у даній статті.

Діалогічне мовлення $є$ невід'ємною частиною всіх суспільних процесів, зокрема тих, які передбачають укладання та реалізацію різного роду угод. Саме під цим кутом зору цікаво розглянути різноманітні концепції суспільного договору, які, починаючи від Гоббса, Локка та Руссо і закінчуючи «Теорією справедливості» Дж. Ролза, обов'язково включають такий чинник як спілкування між індивідами. Адже будьяка угода, навіть якщо вона $є$ гіпотетичною, передбачає активну комунікацію суб'єктів договору у межах рівноправного діалогу. Наприклад, Ж.-Ж. Руссо [8, с. 12-16] виходить з того, що комунікація є необхідною передумовою формування будь-якої угоди, адже без загальної системи знаків, за допомогою якої здійснюється процес спілкування, неможливо уявити шлях до згоди та забезпечення умов достойного існування.

Суб'єктами договору можуть виступати вільні індивіди, які є вільними саме в існуючих соціальних «практиках», тобто вони не визначаються своєю участю в певних економічних, релігійних та інших відносинах (див.: [15, с.221]). В процесі життєдіяльності кожен має право реалізувати свій внутрішній потенціал завдяки активній або пасивній участі в різноманітних сферах людського буття, зокрема в процесі спілкування з іншими суб'єктами. Саме ця участь допомагає визначити життєву позицію людини, виявити її здібності і таланти, що визначає індивіда як носія тієї чи іншої життєвої концепції. Індивід $\epsilon$ вільним в тому сенсі, що не має перешкод у процесі самовизначення та самореалізації, який здійснюється безпосередньо в рамках того чи іншого діалогу.

На думку В.З. Демьянкова, можна розглянути такі умови реалізації діалогу, запропоновані І. Швиталою: 1) існує як мінімум дві особи, які беруть участь в комунікативному обміні; 2) ці особи знаходяться в «центованій взаємодії», тобто їхня увага зосереджена один на одному; 3) посередником в цьому обміні виступає система символів; 4) роль того, хто говорить, і того, хто слухає, має хоча б раз перейти від одного учасника до іншого (див.: [5, с.16]). Якщо всі ці умови виконуються, то тоді, на нашу думку, діалог може виступити в ролі одного з видів дискурсу. І. Яременко [12] звертає увагу на спробу Ю. Хабермаса встановити взаємини між такими поняттями як «дискурс» та «діалог» і зазначає, що Ю. Хабермас не лише дає визначення цим поняттям, але й «обгрунтовує розбіжності між ,дискурсом“ і „комунікативною дією“ 
як двома формами комунікації. У комунікативній дії (інтеракції) постають у взаємному переплетінні мовні вираження, дії й переживання; у дискурсі, навпаки, допускаються тільки мовні вираження; дії й експресія учасників, хоча й супроводжують дискурс, але не є його складовими. Дискурс покликаний відновлювати взаєморозуміння у процесі комунікативної дії» $[12$, с. 49].

Сучасні концепції дискурсу, які передбачають наявність такого компоненту як комунікація, почали виокремлюватися в самостійну галузь в середині 60 -х років ХХ ст. в рамках різноманітних досліджень $[1$, с. 1]. Складність визначення цього поняття полягає в тому, що воно $\epsilon$ предметом вивчення таких гуманітарних наук як лінгвістика, соціологія, філософія, антропологія, літературознавство та психолінгвістика, які так чи інакше займаються вивченням функціонування мови. Однозначного та вичерпного визначення поняття «дискурс» не існує. Надумку А.А.Кибрик і П.Б. Паршина (див.: [6]), найпоширеніші інтерпретації дискурсу можна звести до трьох категорій, кожна 3 яких пов'язана з тим чи іншим філософським напрямком.

До першої категорії відноситься тлумачення американського лінгвіста 3. Харриса, який розглядав дискурс як необхідний елемент уточнення понять діалогу та мовлення. Дискурс може виступати в ролі мовлення в певній комунікативній ситуації або в ролі носія інформації, що вимагає існування діалогічної інтеракції індивідів у межах певного суспільства. Це підкреслює активний характер дискурсу, який протиставляється статичному тексту. В цьому сенсі дискурс, на думку $\Phi$. де Соссюра, виступає в ролі так званого «третього члена» опозиції, який має бути «більш мовленнєвим», ніж саме мовлення, але при цьому характеризуватися лінгвістичними методами. Перша категорія найповніше представлена в роботах дослідників англомовної наукової традиції.

Друга категорія використання терміну «дискурс» пов'язана з структуралізмом та постструктуралізмом, представниками яких є М. Фуко, Ж. Деррида, А. Греймас, М.Пешьо та інші. Дискурс визначається дослідниками як спосіб говоріння і має відповідати на питання який або чий дискурс, оскільки інтерес привертає не сам дискурс, а його жанрові різновиди. Саме тому термін «дискурс» часто заміняється тут поняттям «дискурсивні практики». Таким чином, дискурс виступає в ролі «уточнення» традиційних понять стилю і характеризується мовними рисами, стилістичною специфікою, специфікою тематики та способів дослідження. Все це визначає фонове забарвлення дискурсу, виявляє його особливості, а також забезпечує необхідні умови його існування. 
Третя категорія використання терміну «дискурс» пов'язана з ім'ям німецького філософа та соціолога Ю. Хабермаса. Центральне значення для дослідника має філософія мови та вивчення, власне, проблеми комунікативної взаємодії. Він визначає дискурс як «ідеальний вид комунікації, який виявляється в максимальному можливому відстороненні від соціальної реальності, традицій, авторитета, комунікативної рутини і т. п. і мета якого критичне обговорення і обгрунтування поглядів і дій учасників комунікації» [6]. Ю. Хабермас виходить з того, що кожний індивід є суб'єктом суспільних відношень в «інтерсуб'єктивному життєвому світі», де унікальність індивіда та оточення, в якому він функціонує як самодостатній суб'єкт, є рівнозначними $[11$, с.6]. Індивід проявляє та реалізує свої внутрішні інтенції в рамках дискурсивної практики. Дискурс забезпечує безперервне існування різноманітних комунікативних ситуацій, в яких розкривається внутрішня сутність кожного окремого індивіда, який бере участь в мовленнєвих актах. Ідеї комунікації набувають особливо широкого значення, оскільки спілкування між індивідами поступово стає основою суспільної реальності, на що вказують праці Ю. Хабермаса [11] та інших.

Поряд з сучасними теоріями дискурсу, які були представлені в англомовній науковій традиції (З. Харрис), в структуралізмі та постструктуралізмі (М.Фуко), а також в сучасній німецькій філософії (Ю. Хабермас), важливого значення набуває концепція нейтрального діалогу Б. Аккермана, яка тісно пов'язана з теоріями суспільного договору. Свою концепцію Б. Аккерман виклав у роботі [13].

На його думку, комунікація, що виникає в процесі обговорення суспільної угоди, має чисто інструментальне значення, адже ця комунікація є лише засобом переконання сторін у необхідності укладання угоди. Насамперед створюється така ситуація, де спілкування зводиться до простої обіцянки сторін виконувати угоду, яка встановлює основу соціальних прав і обов'язків, розподіл політичної влади $[13$, с.6]. Таким чином, виникнення діалогу не лише визначається недостатньою кількістю знань суб'єкта суспільних відносин, а значною мірою породжується питанням наслідування політичної влади $[13$, с.6].

В процесі наслідування політичної влади найкращим видом держави та соціальної структури постає такий, який знаходить підтримку і реалізується в умовах так званого нейтрального діалогу. Аккерман вважає, що легітимацію політичних інститутів та соціальних відносин, вирішення політичних конфліктів можливо здійснити у процесі діалогу, який базується на таких принципах як комунікативна рівність, раціональність та нейтральність, причому останній з цих чинників $€$ ви- 
Значальним [13, с.5-20]. Зупинимося на принципах нейтрального діалогу більш детально.

Нейтральний діалог починається з установлення прав громадян на рівні частини наявних ресурсів, що в подальшому визначає ліберальну концепцію рівності, яка є сумісною з соціальним порядком, багатим на розмаїття талантів, особистісних ідеалів і форм суспільства [13, с. 18]. Ці положення Брюс Аккерман називає концепцією рівності без домінації (undominated equality), оскільки жодному індивіду у суспільстві не надається перевага в отриманні тих чи інших привілеїв [13, с.20]. Метою цієї комунікативної концепції рівності є обгрунтування можливості суспільства, де вся влада розподіляється таким чином, що кожен може відстоювати свою позицію у процесі діалогу, який розпочинається зі слів: «Я заслуговую на ці ресурси, тому що я, принаймні, такий же хороший як і ти» [13, с. 19]. 3 точки зору цієї концепції, головне завдання полягає в тому, щоб уявити, що сказали б люди, якби вони мали певну владу, яка відрізнялася від тієї, яку вони мають зараз. На його думку, єдиний спосіб зробити це-скласти уявні діалоги між тими, хто займає різні посади. Якщо створення нейтральних сценаріїв спілкування між суб'єктами є можливим, тоді політична влада може бути узаконеною в якості ліберальної держави. Це так званий діалогічний тест, завдяки якому трансформуються, удосконалюються та об'єднуються в єдину систему різноманітні моральні, законодавчі та релігійні поняття [13, с.20]. Отже, нейтральний діалог є засобом регуляції боротьби за владу, і суспільство може забезпечити цю боротьбу через нейтральний діалог, якщо гарантує дотримання таких умов:

а. Жоден громадянин не перевершує іншого.

b. Кожен громадянин отримує ліберальну освіту.

с. Кожен громадянин розпочинає доросле життя в умовах матеріальної рівності.

d. Кожен громадянин може обмінюватися своїми вихідними правами.

е. Кожен в момент смерті може стверджувати, що він виконав свої ліберальні обов'язки, пропонуючи наступному поколінню структуру влади не менш ліберальну, ніж за його власного існування $[13$, c. 28$]$. 
Якщо всі ці умови виконуються, то лише тоді можна зазначити, що громадяни ліберального суспільства знаходяться в умовах рівності без домінації [13, с. 28]. Отже, ми знову повертаємося до необхідності функціонування нейтрального діалогу, який може бути представлений у формі вільного спілкування між суб'єктами суспільної угоди. Він може бути гарантованим безперервною комунікативною практикою, яка передбачає існування такої форми комунікації як питання-відповідь [13, c. 236]. Таким чином, ідеал концепції рівності без домінації «залишиться віддаленою перспективою», але «чим довше буде існувати діалог, тим довше ліберальна держава залишиться живою реальністю». Саме «нейтральний діалог, а не якесь священне право, $\epsilon$ повноцінною основою нашого життя» [13, с. 342$]$.

Іншим принципом, на засадах якого будується діалог, є раціональність. Кожна людина народжується з певними генетичними здібностями, які допомагають визначити її відношення до влади. Різні генерації можуть трансформувати культурні та матеріальні можливості людей, що в подальшому впливає на пояснення причини наслідування політичної влади та громадянських прав тим чи іншим суб'єктом суспільної угоди. Згідно принципу раціональності громадянські права стали реальністю після того, як люди зіткнулися з недостатньою кількістю влади $[13$, с.5]. На думку Б. Аккермана, якщо ми повністю впевнені, що ніхто не поставить під сумнів наш контроль над деяким об'єктом X, то ми ніколи не порушимо питання про встановлення нашого «права» щодо цього об'єкта [13, с. 333]. «Єдиним контекстом, в якому встановлення права має місце, це той випадок, коли ви передбачуєте можливість спілкування з якимось потенціальним конкурентом» [13, с.334]. Дослідник виходить з того, що принцип раціональності розглядає цей діалог як основу всіх положень права, оскільки «в ліберальній державі всі форми соціальної залежності підпорядковані діалогічним процесам нейтрального спілкування» [13, с. 347].

Головними критеріями принципу раціональності, на нашу думку, є послідовність, несуперечливість та слідування ідеалам, визначеним самим індивідом. В першу чергу розглянемо такий критерій раціональності як послідовність. «Порожній» діалог, діалог, який не має жодного інтелектуального навантаження та не є цілеспрямованим, не може бути послідовним з функціональної точки зору. Між висунутими положеннями повинна існувати логічна послідовність, порушення якої веде до виникнення різноманітних суперечностей [13, с. 7]. Таким чином, наступним критерієм принципу раціональності є несуперечливість. Положення, які відстоює кожен учасник діалогу в одному випад- 
ку, не повинні суперечити тим положенням, які він відстоює в інших випадках, наприклад з метою виправдання свого права на владу [13, c.7]. В процесі спілкування між індивідами виникає необхідність самовираження та прагнення слідувати власним ідеалам. Ці ідеали не $є$ універсальними або загальнообов' язковими, але вони не повинні порушувати загальноприйняті норми моралі або права, які відстоюють індивіди того чи іншого суспільства.

Нарешті, визначальне місце серед принципів діалогу займає нейтральність. В умовах нейтрального діалогу жоден з суб'єктів не висуває претензію на те, що а) його концепція «гарного життя» $є$ кращою, ніж запропонована кимось іншим з його співрозмовників, та б) він перевершує, в будь-якому відношенні, своїх співрозмовників [13, c.11]. Поняття концепції «гарного життя» широко застосовується в політичній філософії, а саме в комунітаріанізмі. Представники цього напрямку наголошують на тому, що кожен індивід має право втілювати свою власну концепцію «гарного життя», що визначає загальний «спосіб життя» всього суспільства. Останній створює базис для суспільного оцінювання різноманітних концепцій «гарного життя» і віддає перевагу в першу чергу тим, які передбачають найбільший внесок в загальну систему блага. Індивід як носій комунікативного мислення є вільним у виборі певної концепції «гарного життя», якщо вона не порушує принципів справедливості і не має значення, наскільки сильно вона відрізняється від «способу життя» всього суспільства [15, с. 235].

Стверджувати, що та чи інша концепція є «кращою», означає відстоювати позицію, що вона більш правильна, ніж інші, що руйнівним чином позначається на самій можливості діалогу. Говорити про те, що той чи інший індивід перевершує інших, означає порушити вихідні положення про природну рівність індивідів. Саме на природну рівність індивідів звернули увагу у свій час філософи Нового часу. Так, Т. Гоббс у роботі «Левіафан» відзначив, що всі люди рівні за своєю природою, що в свою чергу призводить до висування претензій на рівні частини матеріальних благ, що в подальшому веде до «війни всіх проти всіх» (див.: [3, с.96]). 3 метою вирішення даної ситуації виникає необхідність укласти угоду між представниками різних соціальних спільнот. Це може бути здійснено через загальний процес нейтрального спілкування, що забезпечує існування теорій суспільного договору.

Головними критеріями принципу нейтральності, на нашу думку, $\epsilon$ неупередженість та об'єктивність, які нерозривно пов'язані один 3 одним. Бути неупередженим та об'єктивним означає діяти поза колом власних інтересів та оцінювати різноманітні ситуації, беручи до уваги 
особливості висунутого рішення.

Таким чином, на думку Аккермана, існування ліберальної держави базується на трьох взаємопов'язаних принципах: комунікативній рівності, раціональності та нейтральності. 3 нашої точки зору, ці принципи утворюють тріаду ліберальної держави, яку можна представити в формі рівностороннього трикутника, який ми пропонуємо назвати «трикутником Аккермана».

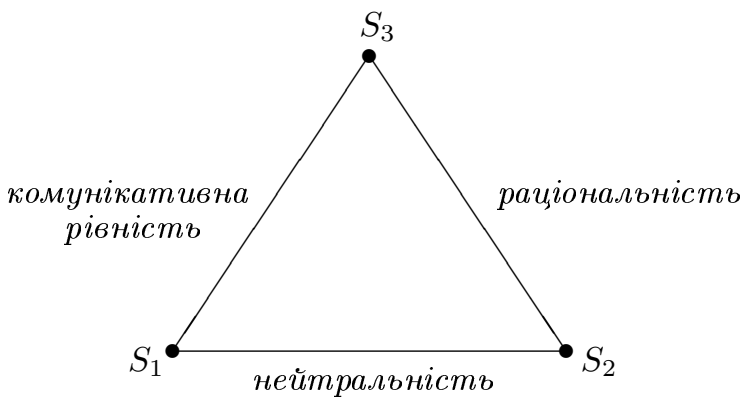

Рис. 1: Трикутник Аккермана

Основою цього трикутника $є$ принцип нейтральності, оскільки він $\epsilon$ визначальним згідно концепції Б. Аккермана. Якщо одна із сторін цього трикутника, яка виражена принципом раціональності або комунікативної рівності, не відповідає протилежній стороні, тобто якийсь з цих принципів порушується, тоді цей трикутник перестає бути рівностороннім, а значить, послаблюються основи ліберальної держави, що в подальшому може привести до повного її руйнування.

Вершинами даного трикутника являються три узагальнених суб'єкта суспільних відношень $\left(S_{1}, S_{2}, S_{3}\right)$. Будь-який діалог передбачає наявність принаймні двох його учасників $\left(S_{1}-S_{2}\right)$, які можуть бути виражені як окремими індивідами, так і соціальними групами, між якими здійснюється процес спілкування. Наявність третього суб'єкта $\left(S_{3}\right)$ пояснюється необхідністю існування того, хто буде знаходитися над попередніми двома суб'єктами та буде здійснювати зовнішне спостереження за процесом діалогічного мовлення, виконуючи, при необхідності, роль своєрідного «арбітра». Цей третій суб'єкт є об'єктивним та неупередженим, що допомагає не завести діалог в глухий кут. 
Б. Аккерман відмічає, що в процесі нейтрального діалогу можливо запропонувати певні результати, які мають бути наслідками вирішення важливих політичних питань [16, с.24]. Такий діалог в чистому вигляді насправді ніколи не мав місця в реальному світі політики, але його можна реалізувати в умовах ідеальної технології справедливості. Вона передбачає відсутність будь-яких практичних труднощів у процесі розподілу недостатніх ресурсів. Ця технологія не ліквідує недостатність, яка є джерелом боротьби за владу, але при цьому визначає ліберальну структуру функціонування суспільства [13, с. 27]. Отже, держава по можливості повинна залишатися нейтральною по відношенню до різних концепцій «гарного життя». Таким чином, основними положеннями, з яких повинна виходити кожна держава в умовах нейтрального діалогу, є наступні:

(1) жодна концепція «гарного життя» не є помилковою;

(2) неможливо стверджувати, що уявлення того чи іншого індивіда про політику, релігію та власний спосіб життя є помилковими;

(3) які б цілі не переслідував індивід, не потрібно вважати, що вони $€$ нічого не значущими;

(4) діяльність, якою бажає займатися індивід, в жодному разі не принижує його честь та гідність;

(5) кожен має право на обрання власної концепції «гарного життя» $[14$, c. $26-31]$.

Отже, можемо дійти висновку, що соціальна справедливість може бути реалізованою лише в умовах нейтрального діалогу, що є необхідним фактором здійснення суспільної угоди. Саме тому діалог неможливо розглядати лише з точки зору інформативного або особистісного аспектів, а краще застосовувати до нього комплексний підхід.

\section{1 Бібліог рафія}

[1] Бабаян B.Н., Круглова С.Л. Теория дискурса в системе наук о языке // Ярославский педагогический вестник. - 2002. № $3(32)$. - C. $1-5$.

[2] Бубер М. Я и Ты. - М.: Республика, 1995. 
[3] Гоббс Т. Левиафан, или материя, форма и власть государства церковного и гражданского. - Сочинения в 2 т. - Т. 2 / Сост., ред., авт. примеч. Соколов В.В.; пер. с лат. и англ. - М.: Мысль, 1991.

[4] Даренский В. Диалогические «механизмы» формирования культурной идентичности // Актуальні проблеми духовності. - Збірка наукових праць / Відп. ред. Я.В.Шрамко. - Випуск 8. - Кривий Ріг: Видавничий дім, 2007.- С. 39-52.

[5] Демъянков В.З. Тайна диалога: (Введение) // Диалог: Теоретические проблемы и методы исследования. - М.: ИНИОН РАН, 1992.

[6] Кибрик А.А., Паршин П.Б. Дискурс [Электронный ресурс]: Энциклопедия "Кругосвет". - http: // www.krugosvet.ru.

[7] Розеншток-Хюсси О. Избранное: Язык рода человеческого. - М.; СПб.: Университетская книга, 2000.

[8] Pуссо ЖК.-ЖК. Об общественном договоре или принципы политического права. - М.: Гос. Соц.-эк. изд.-во, 1983.

[9] Философия ХХ века. Учебное пособие / [Добрынина В.И., Грехнев В.С., Добрынин В.В. и др.].-М.: ЦИНО общества "Знание"России, 1997.

[10] Фуко М. Археология знания. - К.: Ника-Центр, 1996.

[11] Хабермас Ю. Концепция коммуникативной рациональности // Философия эпохи постмодерна. - М.: Мысль, 1995.

[12] Яременко I. Дискурс: специфіка та функції // Тези четвертої студентсько-аспірантської міждисциплінарної конференції «Філософія. Нове покоління».- К.: Видавничий проект Миколи Ковальчука, 2009.

[13] Ackerman B. Social Justice in the Liberal State. - New Haven, Conn.: Yale University Press, 1980.

[14] De Marneffe P. Government Neutrality toward Conceptions of a Good Life: It's Possible and Desirable, But Perhaps Not so Important //http://www.jan.ucc.nau/ edu/d-azmapp/DeMarneffePaper.pdf, 2001. 
[15] Kymlicka W. Contemporary Political Philosophy.-Oxford: Clarendon Press, 1996.

[16] Meidinger E. Administrative Regulation and Democracy // http://www.law.buffalo edu, 1992. 